\title{
PENSION AGE WHICH WOULD GUARANTEE STABILIZATION OF THE OLD AGE DEPENDENCY RATIO
}

\author{
TOMÁŠ FIALA, JITKA LANGHAMROVÁ \\ University of Economics, Prague, Faculty of Informatics and Statistics \\ nám. W. Churchilla 4, 13067 Praha 3, Czech Republic \\ email: fiala@vse.cz, langhamj@vse.cz
}

\begin{abstract}
According to the current legislation the statutory retirement age in the Czech Republic should permanently increase with constant increment 2 months for each subsequent generation. This fact is very often criticized by both politicians and experts. A proposal of halting the rise in retirement age in 2030 at the threshold 65 years is discussed in the Parliament this year.

The main reason for increasing the retirement age in the Czech Republic since 1995 was to eliminate the consequences of population ageing for increasing financial burden of the pension system. Because of this permanent increase the proportion of population size in retirement age and population size in productive age (old age dependency ratio) would be not so rapidly growing after 2040 when numerous generations born in the 70th will retire.

The paper presents computations of the old-age dependency ratio in the Czech Republic for various variants of development of fertility, mortality, migration and retirement age in the case of the Czech Republic and for each variant also the retirement age threshold (changing in time) which would guarantee stabilization of the old-age dependency at its present time value.
\end{abstract}

Key words: old-age-dependency ratio, retirement age, population projection, the Czech Republic

JEL Codes: J11, H55, J26

\section{DOI: 10.15611/amse.2017.20.09}

\section{Introduction}

The ageing of populations is undoubtedly a topic very often discussed not only by demographers, economists and sociologists but also by politicians as well as by general public. Population ageing brings serious economic consequences. As a consequence of the prolongation of life and the relatively low fertility there is an increase taking place in the proportion of seniors in the population. The result of this will understandably be a growing burden on the old-age pension and health care systems (e.g. Bloom, Canning, Fink, 2010).

The old-age-pension system in the Czech Republic is based mainly on so called pay-asyou-go principle. A very important indicator of the financial burden and sustainability of the pension system is the value of the proportion of people in retirement age and people in productive age (old-age dependency ratio) and expected future development of its value. At present times, the lower bound of the productive age is usually 20 years (instead of 15 years before). The upper bound is very often considered to be the age of 65 years, which is (or was until recently) the usual retirement age in many European countries. From the economic point of view an important boundary is the age when there is usually entitlement to an old-age pension (hereafter referred to as retirement age). 
In the Czech Republic, the retirement age is rising steadily since 1996 and according to present legislation (Sbírka zákonů, 1995) and its latest amendment the rise will continue until 2030 when the threshold 65 years will be reached. Therefore, in this paper an adjusted old-age dependency ratio will be considered with lower bound of productive age at 20 years and upper bound equal to the actual retirement age at the time considered. The value of the adjusted oldage dependency ratio is then of course affected not only by the age structure of the population but also by the retirement age threshold. Taking into account the actual retirement age will change the result values and trends of many characteristics of the financial burden of the pension system. See, e.g. Fiala (2013). (Another alternative limit for old age proposed changing in time is, for example, that age at which the average remaining life expectancy is equal to 15 years - Sanderson \& Scherbov, 2010).

In the Czech Republic in the second half of the previous century the retirement age threshold was relatively low. For males it was 60 years of age (with lower threshold for several special professions - pilots, miners etc.). The retirement age for females was differentiated by the number of their children since 53 (5 and more children) until 57 (childless). Females with 2 children (which was the most frequent case) had retirement age 55 years. Despite the unchanged value of retirement age threshold, the value of adjusted old-age dependency ratio has been in the seventies, eighties and early nineties of the previous century relatively stable. The main reason was the fact that the numerous generations of seniors born before the First World War were gradually dying and at the same time numerous cohorts born after the Second World War reached the productive age. Moreover, the life expectancy remained almost unchanged during this period (Arltová, Langhamrová, Langhamrová, 2013).

After 1990 emerged tendencies that the retirement age in the Czech Republic should be increased to the level usual in most European countries (65 years) and the threshold for males and females should be unified. At the same time, demographic prospects showed that preserving the retirement age threshold at the current relatively low age would give rise to the rapid increase of the old age dependency ratio and thus to the rapid increase of retirement pensions expenses.

According to the new legal arrangement (Sbírka zákonů, 1995) of the pension system the retirement age in the Czech Republic started to rise in time since 1996 by 2 months form males and 4 months for females for each subsequent year of births. The period of this rise was several times prolonged. One of the latest novels (Sbírka zákonů, 2011) prolonged the growths of retirement age permanently without any upper limit of retirement age. E. g. persons born in 2013 should have retirement age 73 years, persons born in 2025 retirement age 75 years etc.

The idea of permanent rise of retirement age regardless of the development of life expectancy was often criticized by some politicians. They argued that theoretically it could happen, if the growth of life expectancy would slow down or stop, that in the future many people would not even reach retirement age or would receive a pension only for a relatively short period of time.

One of the themes dealt with in 2014 by the Expert Committee on Pension Reform of the Czech Republic was the adjustment of the age limit for retirement in the Czech Republic. Completely halting any further rise in retirement age after reaching a certain limit (such as 65 years), as proposed by some political parties, would not, however, considered to be suitable. The Council of the European Union, recommends the Czech Republic to Ensure the long-term sustainability of the public pension scheme, in particular by accelerating the increase of the statutory retirement age and then by linking it more clearly to changes in life expectancy. (EU, 2014, p. 15). According to the present projection of the population of the Czech Republic (CZSO, 2013) and other prognoses (e.g. Burcin, Kučera, 2010), it is expected that in the 
Czech Republic there will be a permanent rise in the life expectancy throughout the present century. The continuing rise of the retirement age is thus in accordance with the recommendation of the European Council.

The Expert Committee on Pension Reform therefore finally approved the recommendation that the retirement age (which should be the same for both men and women) and, as hitherto, should depend on the year of birth of the individual. The value of the retirement age for persons born in 1966 and later should in this case be determined so that people reaching senior age should receive an old-age pension on average for the last quarter of their lives (Expert Committee, 2014). For the generations born before 1966 the retirement age should continue to be in accordance with the present legislation, where for every generation of succeeding year of birth the retirement age rises (in comparison with the preceding year generation) for men by 2 months. For women (which have at present time still lower retirement age then males) the rise is by 4 months, after 2019 by 6 months until they reach the level of men. Men born in 1965 should thus retire at the age of 65 years, women with 2 children at 64 years 8 months.

But the final version of the amendment of the law concerning old age pension assumes to stop the rise of retirement age over 65 years after 2030 (Poslanecká sněmovna, 2016). The computations of the retirement age which would lead to receive an old-age pension on average for the last quarter of senior's lives would be carried out regularly each five years, but they will serve only as information for the Government. This amendment has been passed by the Parliament of the Czech Republic in 2017 and it will come into force soon.

This paper presents computation of the future development of the adjusted old-age dependency ratio for the Czech Republic until 2100 based on several variants of population projection using latest available data. The retirement age until 2030 is supposed to grow to 65 years according to current legislation and its latest amendment mentioned above, after 2030 three variants of its future development are assumed. The main goal is to show the impact of further increasing fertility and migration in the future for development of the value of the oldage dependency ratio. Retirement age which will guarantee stabilization of this ratio has been calculated, too.

\section{Population projection and scenarios of its individual variants}

The projection was calculated by the standard component method (e.g. Bogue, Arriaga, Anderton, 1993) with a simplified model of migration. We are considering only immigration which volume in individual years is equal to the assumed net migration. The initial age structure for the projection was the sex-and-age composition of the population of the Czech Republic as of 1.1.2017. The sex-and-age structure of net migration is assumed to be the same as in the period 2012-2015.

The projection scenario proceeded from the scenario of the latest population projection of the Czech Statistical Office (CZSO, 2013). It has been changed taking into account demographic development in 2013-2016 where mainly the rise of fertility but also the rise of migration was much higher than the projection assumed.

The aim of the computation was to show the impact of fertility and migration on the future development of old-age dependency ratio. Thus we considered only one scenario variant for the development of mortality. Due to the fact that the development of mortality during last years did not differ too much from medium variant scenario of the CZSO we used this scenario without any change.

On the other hand, the level of total fertility rates during last years were much higher than assumption of the CZSO projection. According to the preliminary statistical balance the total fertility rate went up above 1.6 children per woman in 2016 (CZSO, 2017) which is the value 
assumed in the CZSO projection only after 2050 just in the high variant. In our fertility scenario, we thus supposed in the low variant maintenance of the total fertility rate at present level (1.6), moderate gradual increase up to (1.75) until 2040 for the medium variant and higher increase up to 1.9 in the high variant.

The average annual net migration was about 19 thousands persons during the period 2014 2016. We assumed constant annual net migration since 2020. For low variant 15 thousands persons per year, for medium variant 25 thousands and in the high variant 40 thousands.

Table 1 shows more detail information of the projection scenario used.

Table 1: Scenarios of mortality, fertility and net migration

\begin{tabular}{|c|c|c|c|c|c|c|c|c|c|c|}
\hline Variant & 2016 & 2020 & 2030 & 2040 & 2050 & 2060 & 2070 & 2080 & 2090 & 2100 \\
\hline \multicolumn{11}{|c|}{ Life expectancy - males } \\
\hline medium & 76.0 & 77.0 & 79.5 & 81.3 & 83.0 & 83.7 & 84.4 & 85.2 & 85.9 & 86.6 \\
\hline \multicolumn{11}{|c|}{ Life expectancy - females } \\
\hline medium & 81.8 & 82.8 & 85.1 & 86.6 & 88.0 & 88.6 & 89.2 & 89.9 & 90.5 & 91.1 \\
\hline \multicolumn{11}{|c|}{ Total fertility rate } \\
\hline low & $1.6^{\mathrm{p}}$ & 1.60 & 1.60 & 1.60 & 1.60 & 1.60 & 1.60 & 1.60 & 1.60 & 1.60 \\
\hline medium & $1.6^{\mathrm{p}}$ & 1.65 & 1.70 & 1.75 & 1.75 & 1.75 & 1.75 & 1.75 & 1.75 & 1.75 \\
\hline high & $1.6^{\mathrm{p}}$ & 1.70 & 1.80 & 1.90 & 1.90 & 1.90 & 1.90 & 1.90 & 1.90 & 1.90 \\
\hline \multicolumn{11}{|c|}{ Net migration (thousands) } \\
\hline low & $20.1^{\mathrm{p}}$ & 15.0 & 15.0 & 15.0 & 15.0 & 15.0 & 15.0 & 15.0 & 15.0 & 15.0 \\
\hline medium & $20.1^{p}$ & 25.0 & 25.0 & 25.0 & 25.0 & 25.0 & 25.0 & 25.0 & 25.0 & 25.0 \\
\hline high & $20.1^{\mathrm{p}}$ & 40.0 & 40.0 & 40.0 & 40.0 & 40.0 & 40.0 & 40.0 & 40.0 & 40.0 \\
\hline
\end{tabular}

${ }^{\mathrm{p}}$ preliminary data Czech Statistical Office

Source: Life expectancy - Czech Statistical Office data. Fertility and migration - author's assumptions

Apart from medium variant of projection (assuming medium variants of mortality, fertility and migration) four following variants were calculated: low variant proposing low fertility and migration, high variant with both high fertility and migration and moreover the variants of low fertility and high migration and finally vice versa the variant of high fertility and low migration. Overview of all variants of scenarios and their characteristic parameters presents Table 2.

Table 2: Variants of population projection

\begin{tabular}{cccc}
\hline Variant of fertility & Variant of migration & $\begin{array}{c}\text { Total fertility } \\
\text { rate } \\
\text { since 2040 }\end{array}$ & $\begin{array}{c}\text { Annual net migration } \\
\text { since 2020 (thousands) }\end{array}$ \\
\hline medium & medium & 1.75 & 25 \\
low & low & 1.60 & 15 \\
high & low & 1.90 & 15 \\
low & high & 1.60 & 40 \\
high & high & 1.90 & 40 \\
\hline
\end{tabular}

Source: author's assumptions

\section{Assumed development of retirement age}

Until the end of 1995 the retirement age threshold in the Czech Republic was relatively low: 60 years for males and 53-57 years for females (depending on the number of children they brought up). Females with two children had retirement age 55 years. Since 1996 then 
there has been enacted gradual rise of the retirement age: by 2 months for males for each subsequent year of births, for females the rise was 4 months (since 2019 will be 6 months) until they reach the level of males. In 2030 the retirement age threshold for males will be exactly 65 years as well as for childless females or females with 1 child. Females with more children will reach the level of males several years later.

According to the current legislation (still in force) the retirement age should continue to rise without any limit (e.g. persons born in 2025 should have retire even in 2100 at the age of 75.). But in April 2017 the Parliament of the Czech Republic passed an important change of this legislation that the rise will be terminated after 2030 when the threshold of 65 years will be reached. The change will come into force soon.

At the same time, there was passed the proposition to calculate the retirement age after 2030 in such a way that the value of the retirement in the future should be determined so that people reaching senior age should receive an old-age pension on average for the last quarter of their lives (Poslanecká sněmovna, 2016). But this computations will have only informative character, they do not undertake the Parliament to change the retirement age in such a way.

That is why we shall consider in our projection 3 variants of retirement age development after 2030 (until 2030 we suppose the rise up to 65 years by current legislation) (See Fig. 1)

a) Prolongation of the rise according to "old" legislation up to 75 years in 2100 .

b) Retirement age defined so that people reaching senior age should receive an old-age pension on average for the last quarter of their lives.

(rise according to current legislation until 2040, subsequently slowdown of the rise to 15 days for each subsequent year of births - Fiala, Langhamrová, 2015).

c) Retirement age equal 65 years since 2030 until 2100 .

Figure 1: Variants of development of retirement age

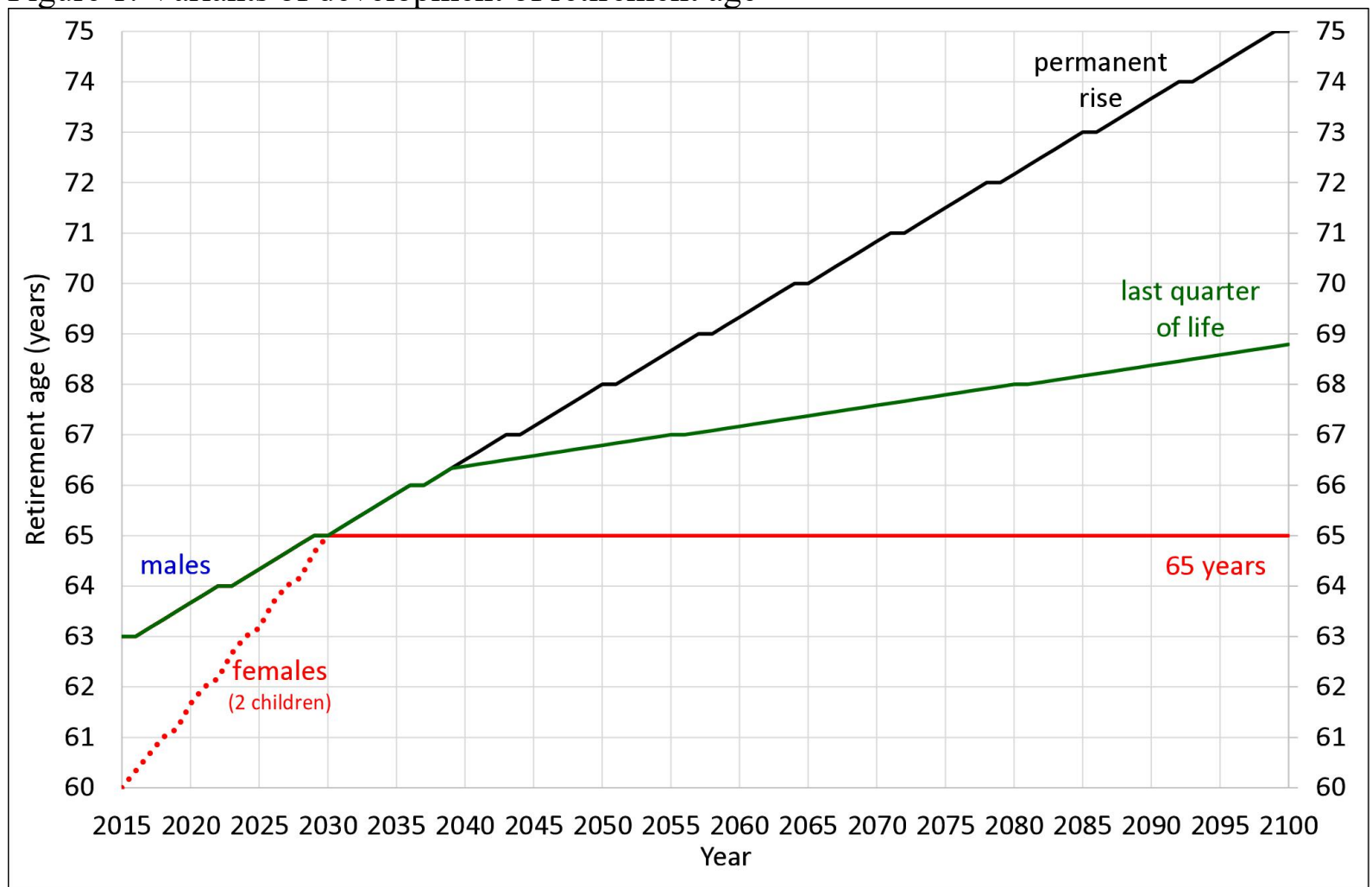

Source: Law No 155/1995, authors' computations.

Due to the long-term change of retirement age in the Czech Republic the standard upper bound of productive age (65 years) is very misleading. We shall thus consider the upper 
threshold of productive age to be equal to the retirement age at the given moment according to variant supposed. For the sake of simplicity, we assume that every woman brought up two children. The lower bound of productive age was 20 years. If the value retirement age was not integer we divided the persons at the age equal the integral part of retirement age into "productive" and "post-productive" using linear interpolation.

The number of persons in productive age at time $t$ has been computed by the following formula (separately for males and females)

$$
L_{t}=\sum_{x=20}^{\left[r_{t}\right]-1} S_{t, x}+\left(r_{t}-\left[r_{t}\right]\right) \cdot S_{t,\left[r_{t}\right]},
$$

where

$S_{t, x}$ is the number of persons of the age $x$ at time $t$,

$r_{t}$ is the retirement age at time $t,\left[r_{t}\right]$ denotes its integer part, similarly, the number of persons in post-productive (retirement) age was

$$
R_{t}=\sum_{x=\left[r_{t}\right]+1}^{110} S_{t, x}+\left[1-\left(r_{t}-\left[r_{t}\right]\right)\right] \cdot S_{t,\left[r_{t}\right]} .
$$

E.g. if the retirement age would be 60 years 4 months then $1 / 3$ of people at the age of 60 are classified to productive age while the rest $2 / 3$ belong to post-productive age. Mid-year population of productive, post-productive age, respectively $\left(\bar{L}_{t}, \bar{R}_{t}\right)$ is then calculated as the arithmetic mean of population as of the $1^{\text {st }}$ January in years $t$ and $t+1$.

The adjusted old age-dependency ratio has been then calculated for each year $t$ as the proportion of mid-year post-productive and productive population

$$
A O A D R_{t}=\frac{\bar{R}_{t}}{\bar{L}_{t}}
$$

where $t$ denotes the population in the as of $1^{\text {st }}$ January in the year $t$. It is a (very rough) indicator of the financial burden of the pay-as-you go pension system in the year $t$.

Changes in the population age structure may cause fluctuations of the values of old-age dependency ratios in time. To eliminate these fluctuations, we have computed also the values of average adjusted (cumulative) old-age dependency ratio for a time period $t_{0}-t$

$$
A O A D R_{t_{0}-t}=\frac{\sum_{u=t_{0}}^{t} \bar{R}_{u}}{\sum_{u=t_{0}}^{t} \bar{L}_{u}} .
$$

\section{Development of the old-age dependency ratio in particular variants of demographic development and retirement age}

Rise of total fertility rate to 1.75 together with annual net migration 25 thousand persons (medium variant) would be sufficient for sustainable development of the population size. The number of inhabitants would fluctuate between 10.5 and 11 million. If the net migration will be lower (15 thousand per year only), higher increase in fertility (TFR up to 1.9) will be necessary for sustaining the population size at present level. High net migration (40 thousand) would increase the population size almost to 12 million even if the fertility will remain at present relatively low level. Low fertility and low migration would result in the gradual drop of population size below 9 million while high migration in combination with high fertility would cause relatively high increase of the number of inhabitants over 14 million (Fig. 2). 
Termination of the rise of retirement age at the age level 65 years in 2030 would result in high increase of the adjusted old-age dependency ratio after this year. The ratio would reach maximal values in the fifties; while all the numerous cohorts of inhabitants born un the seventies will after 2040 gradually reach the retirement age. Even in the high variant the ratio would be almost $55 \%$ while in the low variant the value will be about $66 \%$. The following drop will be only modest and in the end of the century the values of the ratio would be about 45-62\% depending on the variant of demographic development (Fig. 3). It means that the number of old-age pensioners per 100 persons in productive age would be in the medium variant by about $30 \%$ higher than at present time, in the minimum variant even more than by $50 \%$ higher which will in proportion of this increase the burden of the pension system. Because of the fact, that the proportion of employed persons among persons in productive age is about $70-80 \%$ there will be almost 1 old age pensioner to 1 employed person in the minimum variant.

Figure 2: Population size

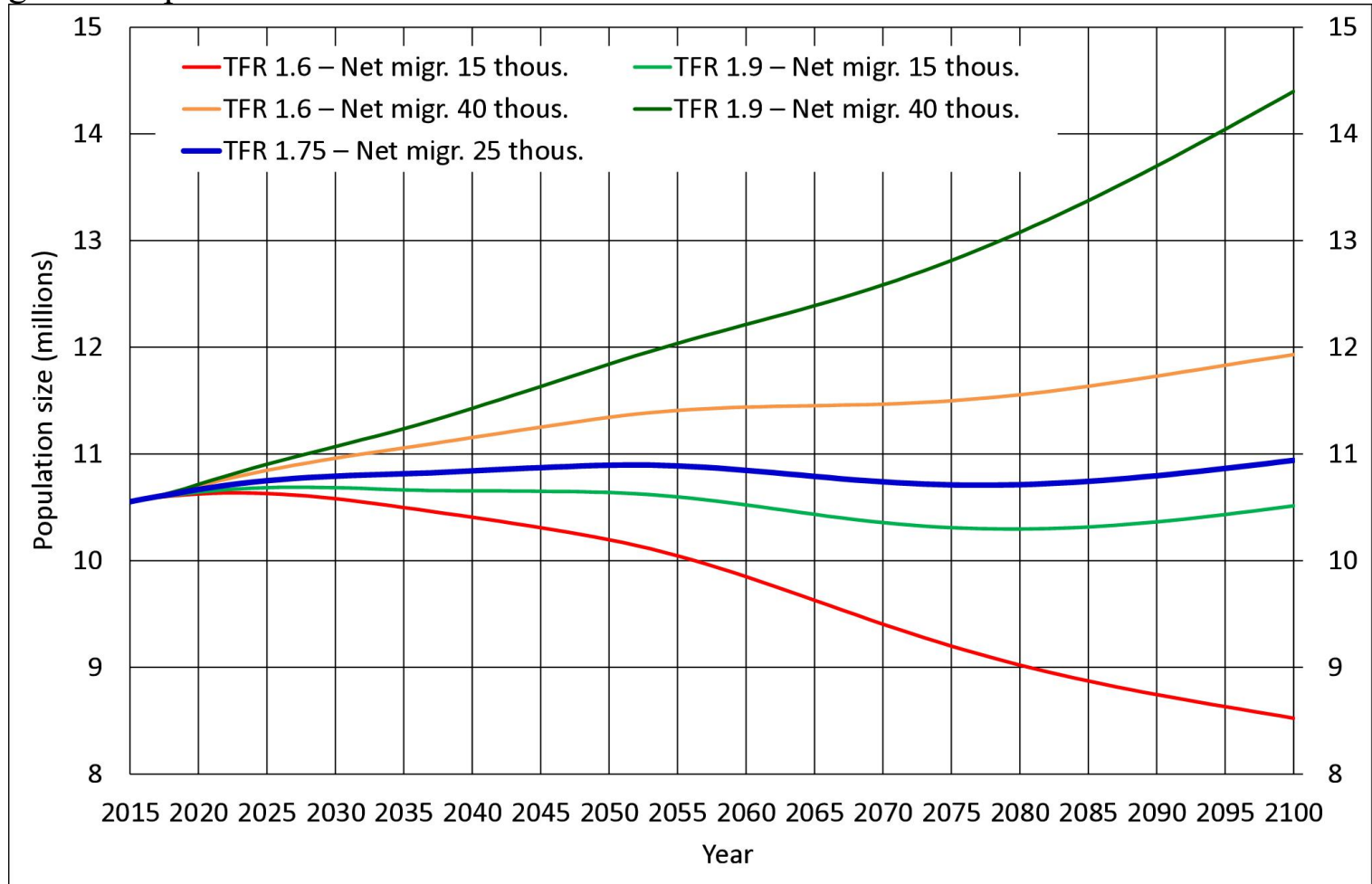

Source: authors' computations.

The value of cumulative adjusted old-age dependency ration would in the second half of the century be about $45-55 \%$ (Fig. 4) which means that in the period analyzed the expenses for old-age pensions would be about $15-35 \%$ higher than in 2015 .

After slowing down the rise of retirement age after 2040 (at the age level over 66 years) to fulfill the criterion that the average period of the old-age pension receipt should be about $1 / 4$ of the total lengths of senior's life - the rise of the adjusted old-age dependency ratio values will be by far not so high as in the previous case. Its maximal values would reach about $47 \%$ (high fertility and migration variant) to $58 \%$ (low variant) and after they will drop by about 5 percentage points to $35-50 \%$. In the medium variant as well as for the combination of high fertility and low migration or vice versa the values of the ratio in 2100 would be only a little bit higher than at present time (Fig. 5). In the low fertility and low migration variant the number of old-age pensioners per 100 persons in productive age would be about $20 \%$ higher while in high variant it would be about $10 \%$ lower than at present time. 
20th International Scientific Conference AMSE

Applications of Mathematics and Statistics in Economics 2017

Szklarska Poręba, Poland 30 August 2017 - 3 September 2017

Figure 3: Old-age dependency ratio for pension age stabilized at 65 years

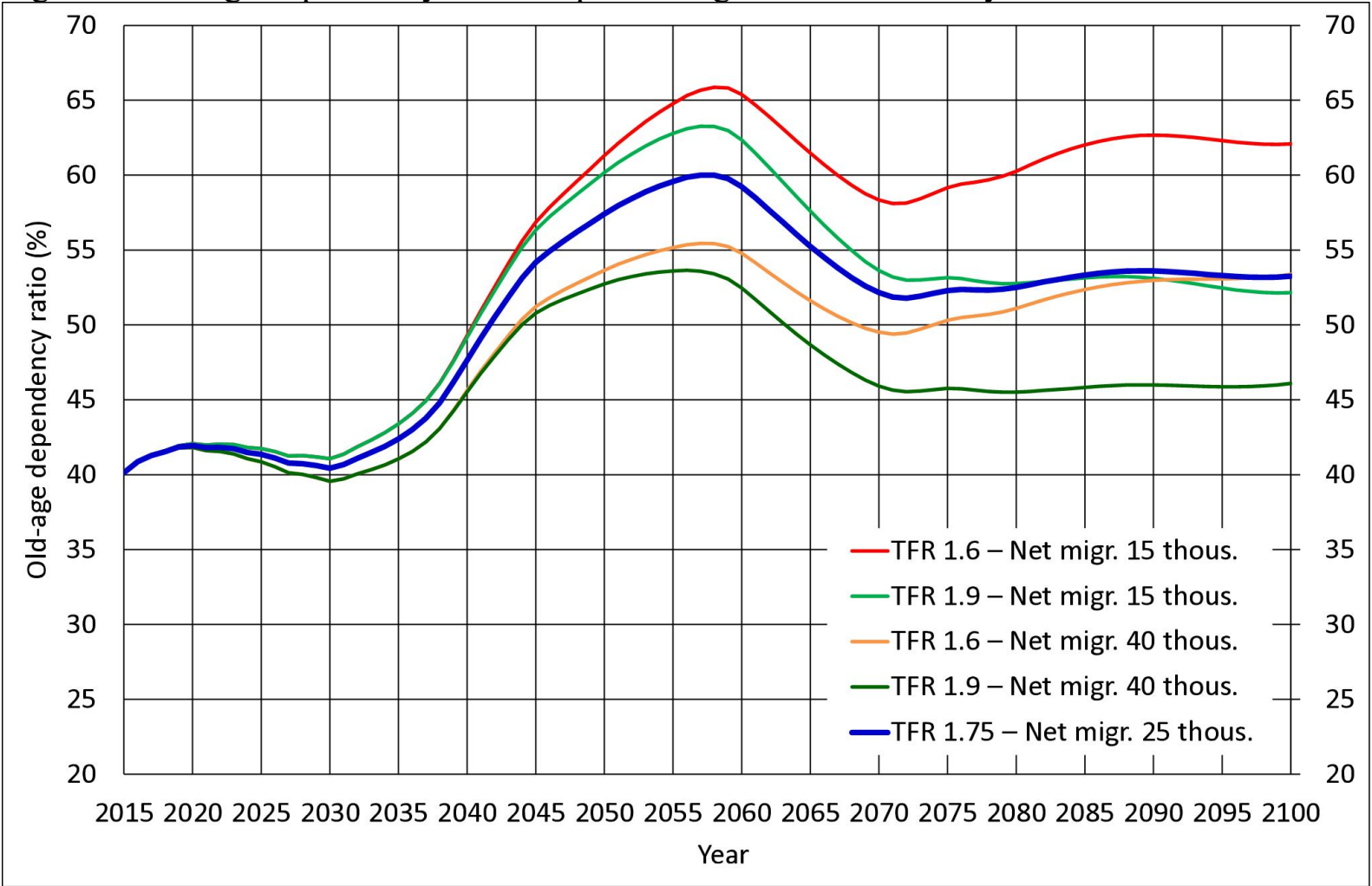

Source: authors' computations.

Figure 4: Cumulative old-age dependency ratio for pension age stabilized at 65 years

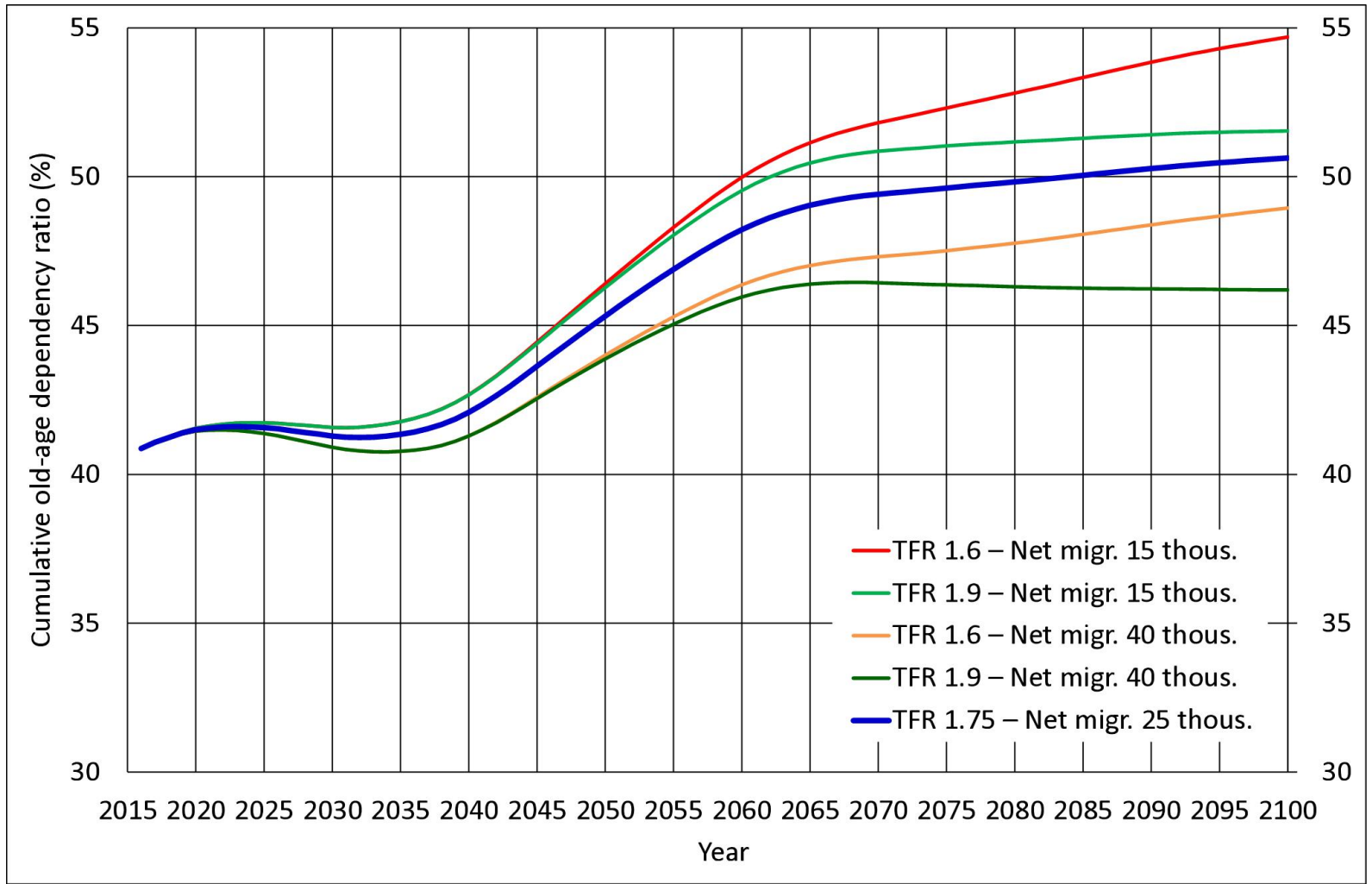

Source: authors' computations. 
20th International Scientific Conference AMSE

Applications of Mathematics and Statistics in Economics 2017

Szklarska Poręba, Poland 30 August 2017 - 3 September 2017

Figure 5: Old-age dependency ratio for pension age for pension receipt $25 \%$ of the life

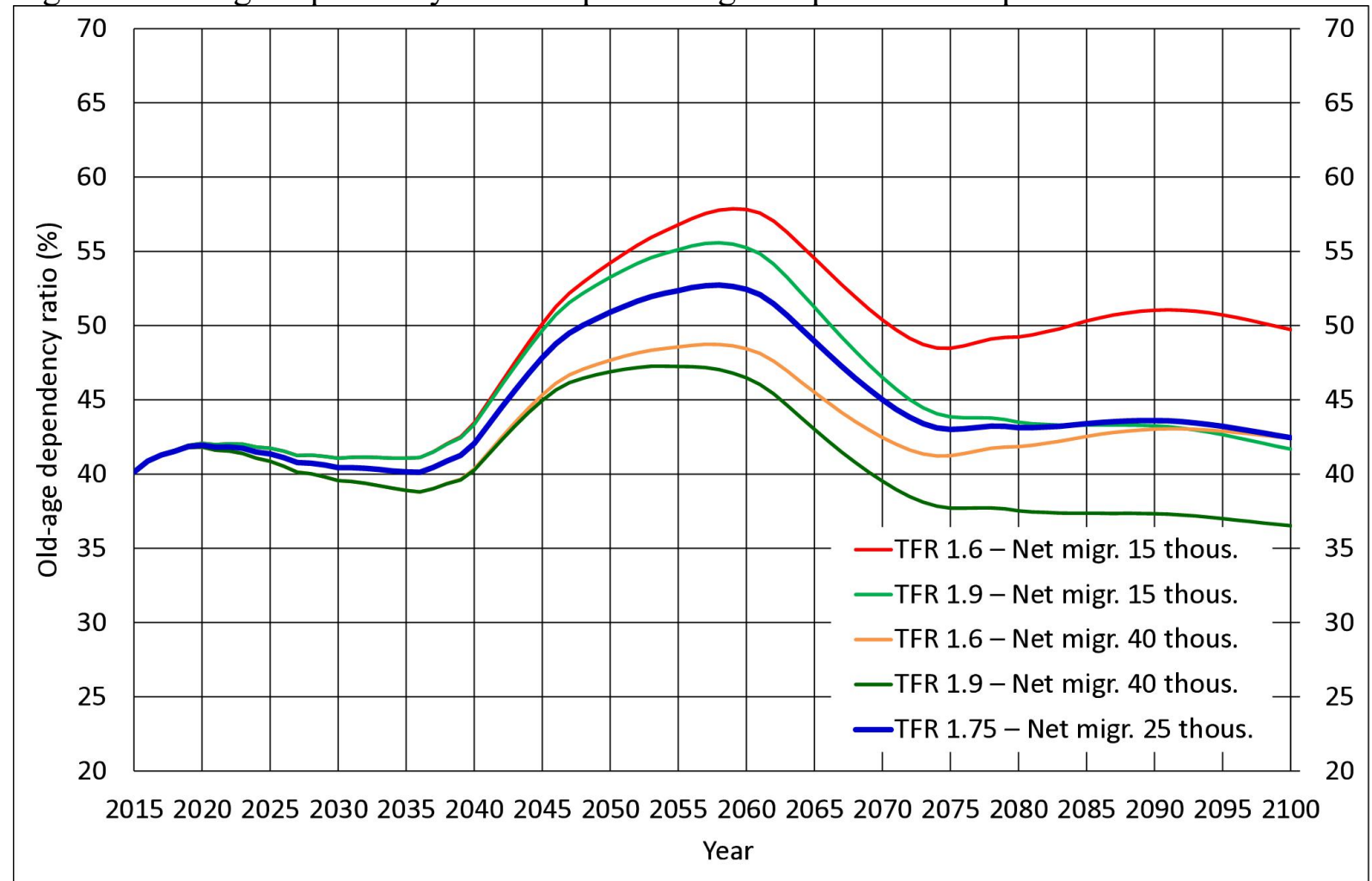

Source: authors' computations.

Figure 6: Cumulative old-age dependency ratio for pension age for pension receipt $25 \%$ of the life

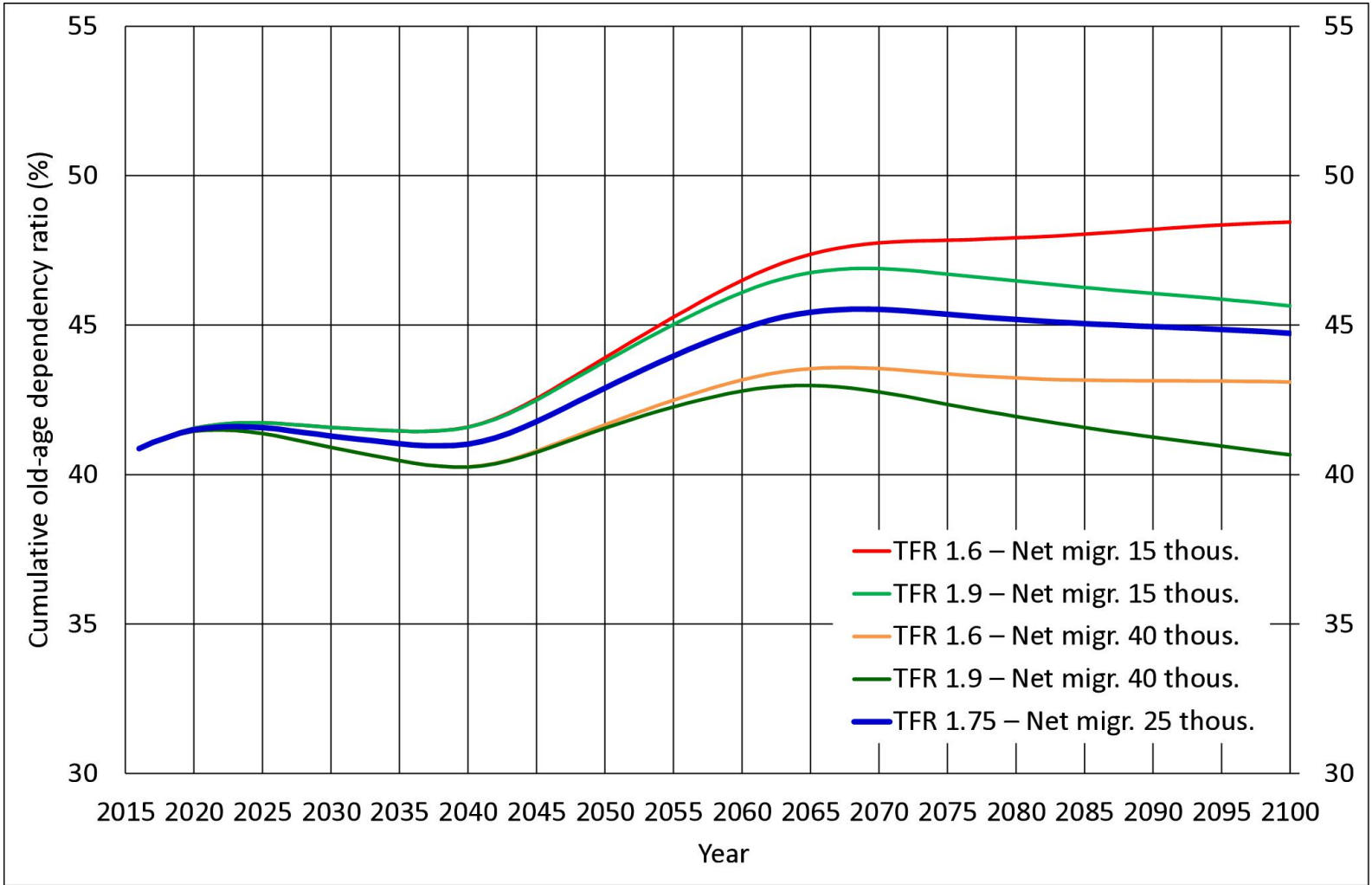

Source: authors' computations. 
20th International Scientific Conference AMSE

Applications of Mathematics and Statistics in Economics 2017

Szklarska Poręba, Poland 30 August 2017 - 3 September 2017

Figure 7: Old-age dependency ratio for pension age rising up to 75 years

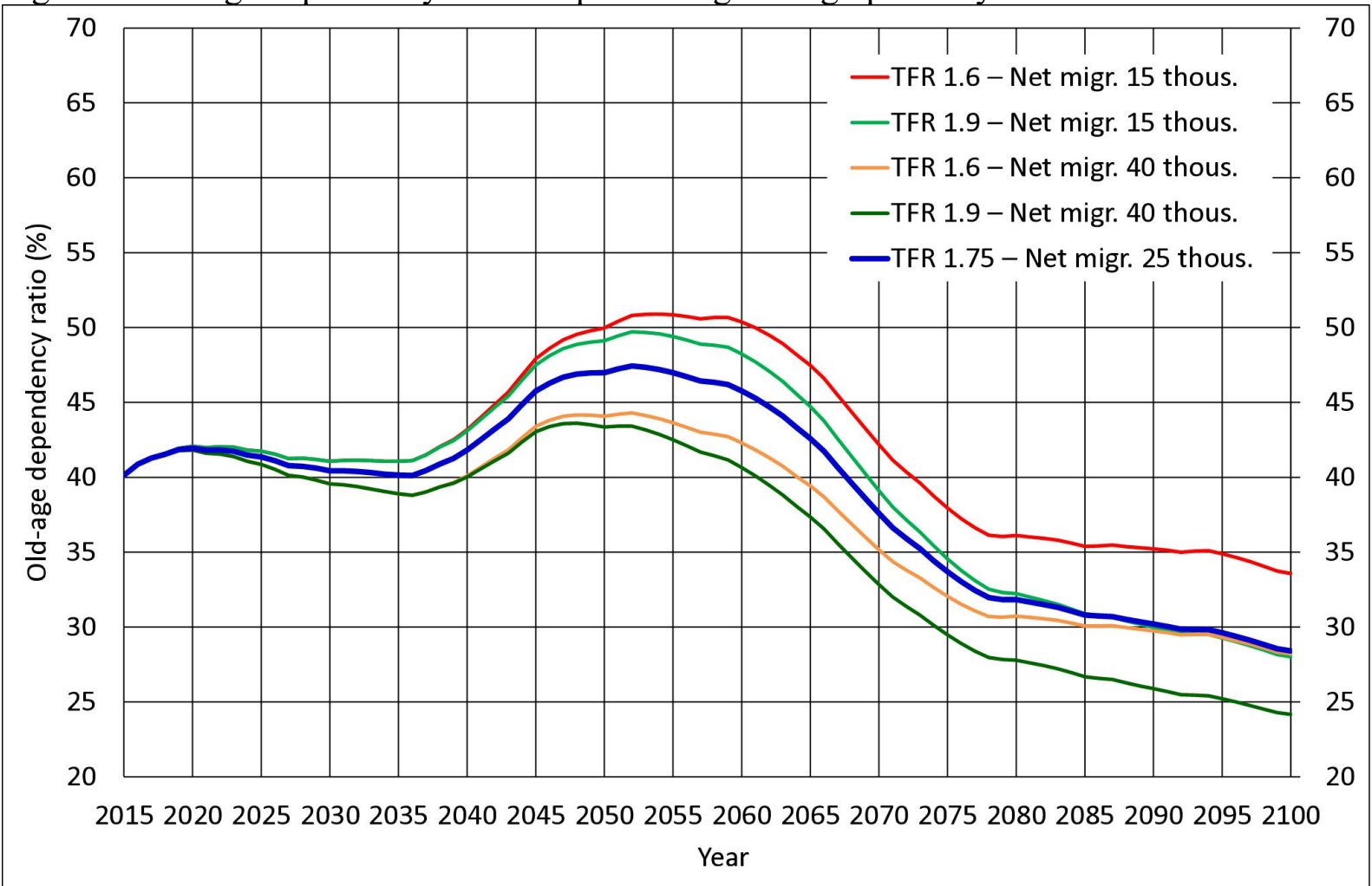

Source: authors' computations.

Figure 8: Cumulative old-age dependency ratio for pension age rising up to 75 years

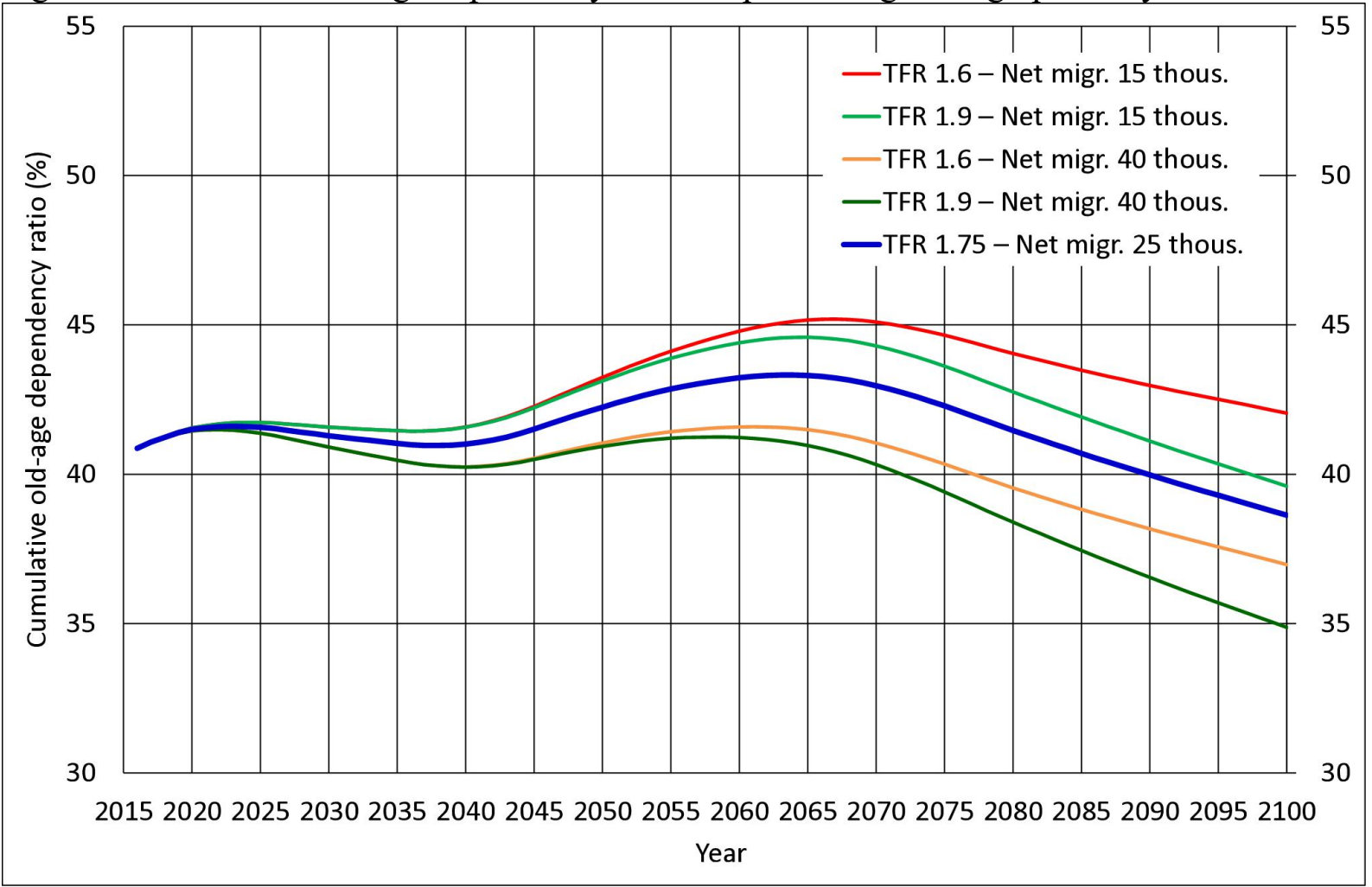

Source: authors' computations. 
Due to the increase in the fifties the value of cumulative adjusted old-age dependency ratio would in the second half of the century be about $40-50 \%$ (Fig. 6). The average expenses for the whole period analyzed for old-age pensions would thus be in the medium variant about $10 \%$ higher than in 2015 . For the minimum fertility and migration variant they would be about $20 \%$ higher while in the maximum variant their value would be almost the same as at present time. This variant can thus be considered to bring long-term sustainable burden of the pension system.

Even the permanent rise of the retirement age until 2100 up to 75 years according to current legislation (without the amendment mentioned) - the values of the adjusted old-age dependency ratio values will grow a little bit after 2040 when the numerous cohorts of persons (born during the baby-boom in the seventies of the previous century) will gradually reach the retirement age. But the maximal value of the ratio in the low fertility and low migration variant would not be too much higher than $50 \%$ while for the high fertility and migration variant the value of the ratio would be lower than $45 \%$. The continual raise of the retirement age will result in relatively rapid drop of the values of the ratio in the late fifties, sixties and seventies when the numerous generations of the old-age pensioners mentioned will gradually die. Since 2070 the value of the ratio would be lower than at present time for all variants. In the end of the century the ratio values would be only about $25-35 \%$. (Fig. 7). It means that the number of old-age pensioners per 100 persons in productive age would be about $20-40 \%$ lower than at present time.

Due to the increase in the fifties the value of cumulative adjusted old-age dependency ratio would in the end of the century be a little bit higher, about 35-42\% (Fig. 8). Nevertheless it means that the average number of old-age pensioners for 100 persons in productive age in the whole period analyzed would thus be in all variants (except that of low fertility and low migration) lower than at present time and for the low variant mentioned it would be only about $4 \%$ higher.

\section{Retirement age guaranteeing stabilization of the old-age dependency ratio}

It is clear, that fixed value of retirement age (65 years) since 2030 would result in much higher values of the average cumulative adjusted old-age dependency ratio (4) until 2100 than at present times (Fig. 4). On the other hand if the retirement age would continually increase up to 75 years until 2100, the value of the ratio would be lower (with the exception of the variant of low both fertility and migration) - Fig. 8. The supposed proposal assuming receipt the oldage pension on average for the last quarter of the life span seems to be a reasonable compromise between fixed value of retirement age and its permanent "mechanical" increase regardless of the development of mortality. The value of the average cumulative adjusted oldage dependency ratio until 2100 would be a little bit higher than in 2016 .

Slight rise in retirement age would thus guarantee that the value of the average cumulative adjusted old-age dependency ratio until 2100 could be approximately the same as that in 2016 . To fulfill the principle that the time of pension receipt should be a proportion of the total expected life span, relative (not absolute) increase of retirement age for generations born after $1965^{1}$ has been applied. At the same the assumption that the difference in retirement age between neighboring generations will not be higher than 3 months was accepted. The retirement age guaranteeing stabilization of the old-age dependency ratio for generations born after 1965 has been thus calculated according to the formula

$$
r a_{g}=\min \left\lfloor r a_{g-1}+1 / 3 ; r a_{g, 25 \%} \cdot(1+\delta)\right\rfloor,
$$

\footnotetext{
${ }^{1}$ According to legislation proposed no change of present retirement age for people born until 1965 should be accepted.
} 
20th International Scientific Conference AMSE

Applications of Mathematics and Statistics in Economics 2017

Szklarska Poręba, Poland 30 August 2017 - 3 September 2017

Figure 9: Pension age guaranteeing the stabilization of the old-age dependency ratio

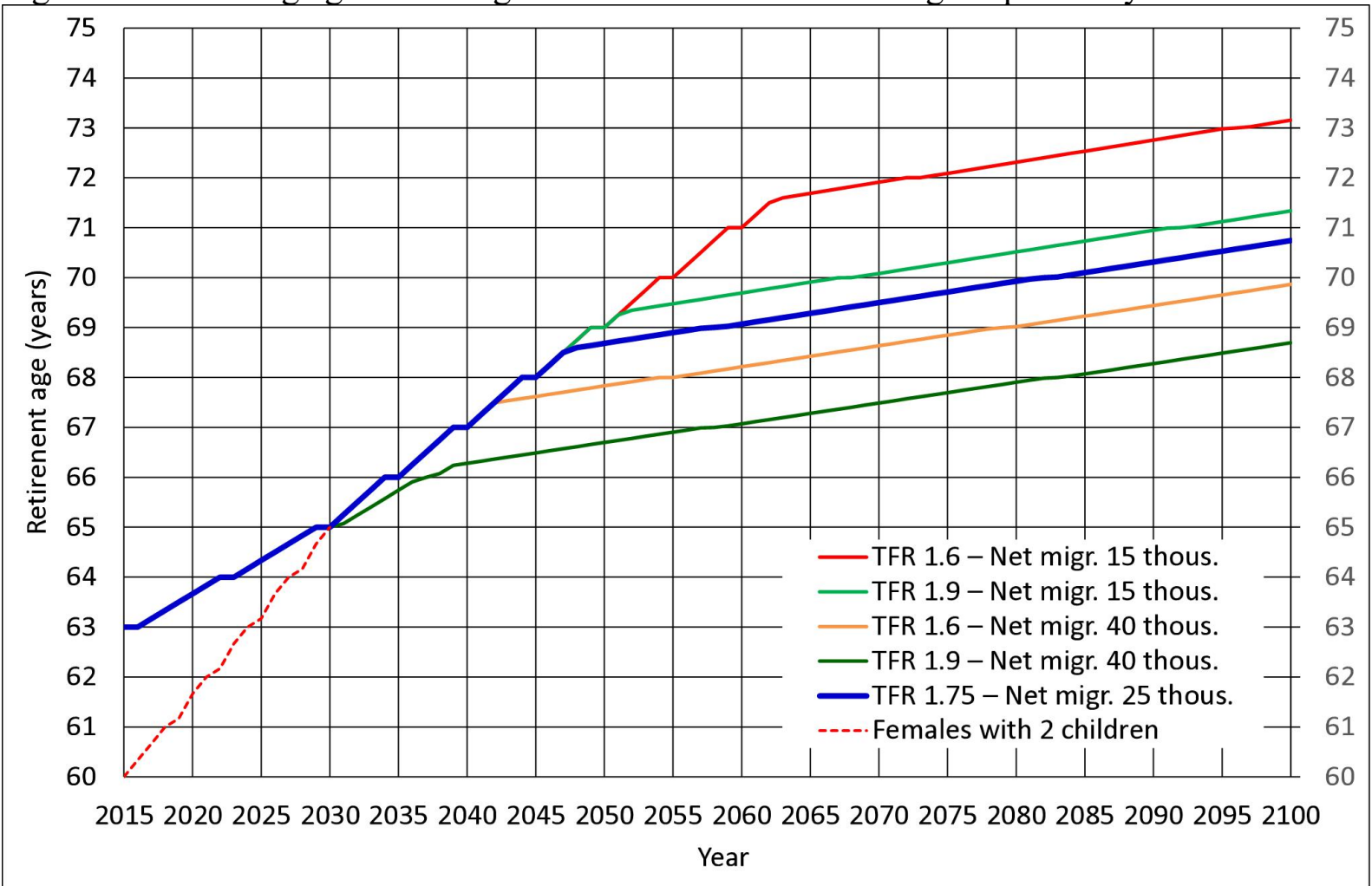

Source: authors' computations.

Figure 10: Old-age dependency ratio for pension age guaranteeing the stabilization of the oldage dependency ratio

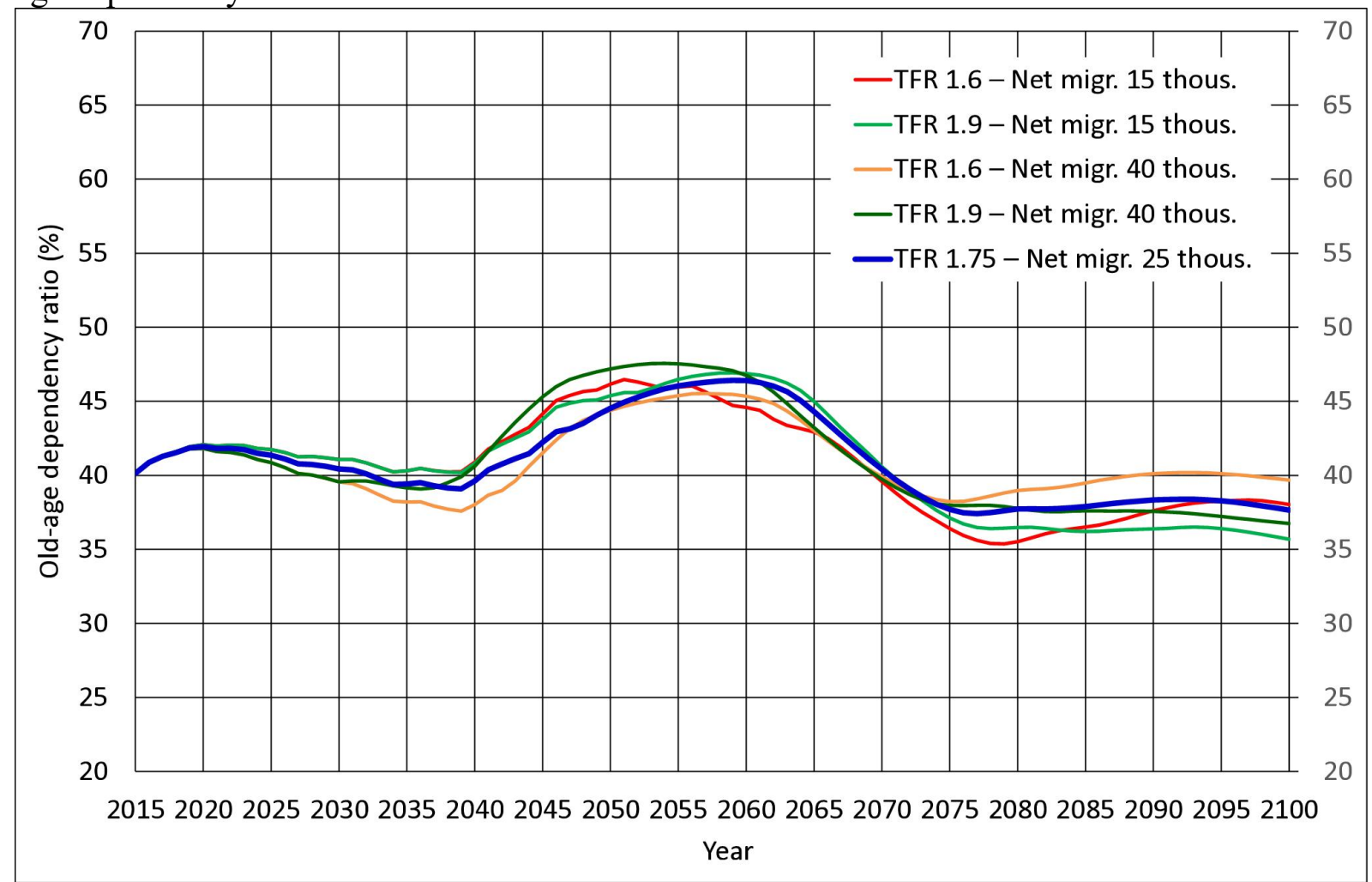

Source: authors' computations. 
Figure 11: Cumulative old-age dependency ratio for pension age guaranteeing the stabilization of the old-age dependency ratio

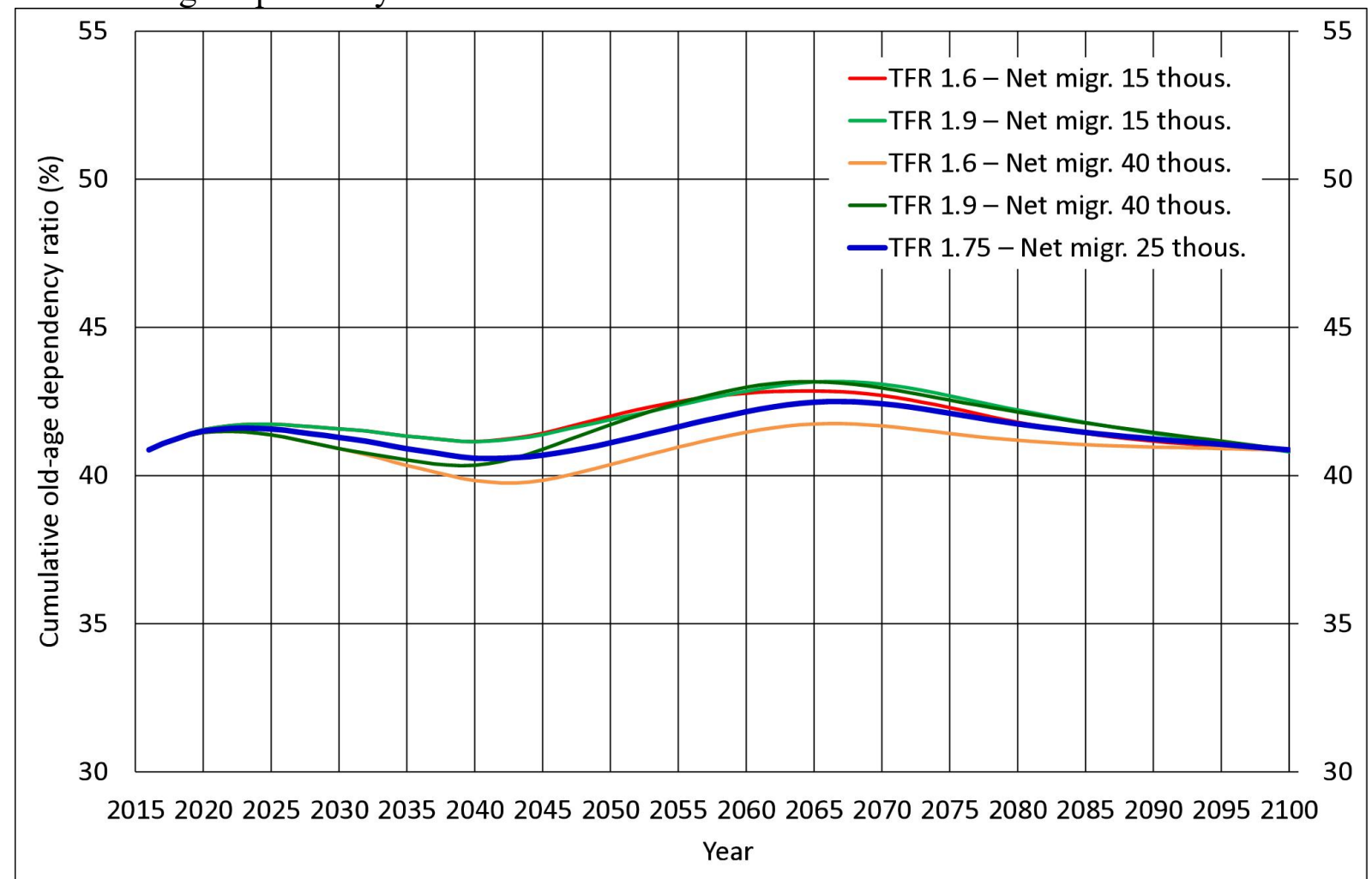

Source: authors' computations.

where $r a_{g}$ is the retirement age for persons born in the year $g, r a_{g, 25 \%}$ is the retirement age guaranteeing for this generation pensions receipt for the last quarter of the expected life span. The value of the parameter $\delta$ is the (unique) solution of the equation

$$
A O A D R_{2017-2100}^{\text {cum }}=A O A D R_{2016} \text {. }
$$

In the variant of low fertility and low migration as well the pension age guaranteeing stabilization of the old-age dependency ratio had to reach 71 years in 2060 and it would grow to more than 73 years until 2100 . The time of pension receipt would converge to about $20 \%$ of the total life span. For the medium variant the pension age should grow to 69 years until 2050 and continue to grow to 71 years in the second half of this century. The pension would be received for about $22.5 \%$ of the total life span. In the case of high fertility and high migration no additional increase of pension age would be necessary. After reaching the level 66.5 years in 2040 it would continue to rise very slowly to 69 years until 2100 . The proportion of pension receipt would be about one quarter of the total life span (Fig. 9).

The differences in values of the old-age-dependency ratio (Fig. 10) are relatively low because higher proportion of older persons is compensated by rise in retirement age. The values of cumulative ratio for the whole period of projection 2017-2100 are in all variants equal to the value in 2016 (Fig. 11). It indicates that the pension age proposed (Fig. 9) would result in long term stabilization of the old-age-dependency ratio

\section{Conclusion}

The old-age dependency ratio is of course a very rough estimate of the financial burden of the old-age pension system of the pay-as-you-go type. While the number of persons in postproductive age is relatively accurate estimate of the number of persons receiving old-age 
pension, the number of employed persons (paying social security insurance contributions) is much lower than the number of persons in productive age, especially in higher age groups. In next decades, the Czech Republic will face the challenge of relatively rapid increase of labor force older than 50 years of age. (Fiala, Langhamrová, 2014) and it will be necessary to ensure economic participation of these persons.

Real financial burden of the pension system depends thus not only on the value of the adjusted old-age dependency ratio but also on the gender and age population structure, on employment rates, on the average amount and distribution of incomes and pensions, on inflation rate and pension adjustment in time valorization and of course on the rate of economic growths. Nevertheless, increase in the value of the old-age dependency ratio indicates probable increase of expenditures on old-age pensions.

To ensure appropriate pension for seniors is a very important task for social policy. It is evident that after taking into consideration the raising of the retirement age the given demoeconomic indicators will have completely different values and there will also be a change in their development trend.

Even though the calculations made are very much simplified, they do capture the main trends of the development of the pension system and its dependence on the pension age. They show that the constant raising of the retirement age can, in the long term, contribute in a promising manner to the financial stability of the present pension system with the medium variant of demographic development while, on the other hand, permanent fixation of the retirement age at the level 65 years after 2030 would result in relatively high growths of expenditures for old-age pensions mainly due to the fact that after 2040 the numerous generations born in the seventies of the previous century will gradually retire.

First and foremost, however, it is necessary that there should be sufficient suitable jobs for persons of higher age groups, especially those over 60. Especially in some regions it may be a little complicated issue. Apart from this it will be essential to resolve the pension security of persons in professions where the raising of the retirement age over 65 years is not realistic.

The calculations show, according to expectation, the relatively strong dependence of the burden on the pension system on the future development of fertility and migration. In any case one of the ways to ensure the stability of the pension system in the future should be (apart from a suitable employment policy aimed in particular at the older age categories) also a suitable population and family policy and migration policy. One of the possibilities would be take into account a greater extent in the pension system the number of properly reared children, whether in the form of lower payments by parents or higher pensions or perhaps a combination of the two. Such models have already been proposed.

This would be in accordance with the often-mentioned principle of increased dependency, for in the current pension system there are two types of merit. Apart from the level of the payments into the pension system, which ensure the paying out of pensions to existing seniors, the upbringing of children - future payers - also deserves merit. Apart from this, taking children more into account would be a logical reaction to one of the causes of the ageing of the population - the low birth-rate - just as the raising of the retirement age is a logical reaction to the second cause - growing life expectancy.

\section{Acknowledgements}

This article was supported by the Grant Agency of the Czech Republic No. GA ČR 1513283S under the title Projection of the Czech Republic Population According to Educational Level and Marital Status. 


\section{References}

[1] Arltová, M., Langhamrová, Jitka, Langhamrová, Jana. 2013. Development of life expectancy in the Czech Republic in years 1920-2010 with an outlook to 2050. Prague Economic Papers. Vol. 22, No. 1, pp. 125-143. ISSN 1210-0455.

[2] Bloom, D.E.; Canning, D.; Fink, G. 2010. Implications of Population Ageing for Economic Growth. Oxford Review of Economic Policy. Vol. 26, No. 4, pp. 583-612.

[3] Bogue, D. J., Arriaga, E. E., Anderton, D., L. (eds.). 1993. Readings in Population Research Methodology Vol. 5. Population Models, Projections and Estimates. United Nations Population Fund, Social Development Center, Chicago, Illinois.

[4] Burcin, B., Kučera, T. 2010. Prognóza vývoje obyvatelstva České republiky do roku 2070. In: Bartoňová D. a kol.: Demografická situace České republiky: proměny a kontexty 1993-2008. Praha: Sociologické nakladatelství SLON, s. 181-212. ISBN 978-80-7419024-7.

[5] CZSO (Czech Statistical Office). 2013. Projekce obyvatelstva České republiky do roku 2100. https://www.czso.cz/csu/czso/projekce-obyvatelstva-ceske-republiky-do-roku-2100n-fu4s64b8h4. [Cit. 2015-03-25].

[6] CZSO (Czech Statistical Office). 2017. News Releases. Population change - year 2016. https://www.czso.cz/csu/czso/ari/population-change-year-2016 [Cit. 2017-04-25].

[7] EU. 2014. Council Recommendation of 8 July 2014 on the National Reform Programme 2014 of the Czech Republic and delivering a Council opinion on the Convergence Programme of the Czech Republic. Official Journal of the European Union (2014/C 247/03) content/EN/TXT/PDF/?uri=CELEX:32014H0729(03)\&from=CS

http://eur-lex.europa.eu/legal-

[8] Expert Committee on Pension Reform Czech Republic. 2014. Final Report on Activities in http://www.duchodova-komise.cz/wp-content/uploads/2015/02/Final-report-CoE2014.pdf

[9] Fiala, T. 2013. Reducing the Consequences of Population Ageing for the Pension System by Raising the Retirement Age in the Czech Republic. (2013) In: The 7th International Days of Statistics and Economics [CD]. [online] Praha, 19.09.2013 - 21.09.2013. Slaný: MELANDRIUM, 2013, pp. 398-407. ISBN 978-80-86175-87-4. Retrieved April 16, 2015 from: http://msed.vse.cz/files/2013/100-Fiala-Tomas-paper.pdf.

[10] Fiala, T., Langhamrová, J. 2014. Increase of Labor Force of Older Age - Challenge for the Czech Republic in Next Decade. In: 17th International Conference Enterprise and Competitive Environment 2014. [online] Brno, 06.03.2014 - 07.03.2014. Amsterdam: Elsevier, 2014, s. 144-153. Procedia Economics and Finance 12. ISSN 2212-5671. URL: http://www.sciencedirect.com/science/article/pii/S221256711400330X.

[11] Fiala, T., Langhamrová, J. 2015. Computation of retirement age based on generation life tables. In: 16th ASMDA 2015 Conference and Demographics 2015 Proceedings [online]. Piraeus, 30.06.2015 - 04.06.2015. Piraeus: University of Piraeus, 2015, s. 199208. ISBN 978-618-5180-05-8. http://www.asmda.es/images/1_EG_ASMDA2015_Proceedings.pdf.

[12] Poslanecká sněmovna Parlamentu České republiyky. 2016. Sněmovní tisk 912/0, část č. 1/6. Novela z. o důchodovém pojištění citace 23. 10. 2016, dostupné na: http://www.psp.cz/sqw/text/tiskt.sqw? $=7 \& \mathrm{CT}=912 \& \mathrm{CT} 1=0$

[13] Sanderson, W., Scherbov, S. 2010. Remeasuring ageing. Science 329, pp. 1287-1288. 
[14] Sbírka zákonů. 1995. Zákon 155/1995 Sb (Law No. 155/1995 Coll.). O důchodovém pojištění, aktuální znění, př́loha

[15] Sbírka zákonů. 2011. Zákon 220/2011 Sb. (Law No. 220/2011 Coll.). ze dne 21. června 2011, kterým se mění zákon č. 155/1995 Sb., o důchodovém pojištění, ve znění pozdějších předpisů, a některé další zákony. 